\title{
PENERAPAN METODE TEOREMA BAYES UNTUK MENDIAGNOSA PENYAKIT PARU OBSTRUKTIF KRONIK (PPOK)
}

\author{
THE IMPLEMENTATION OF THEOREME BAYES METHOD FOR DIAGNOSING THE \\ LUNG DISEASE CHRONIC OBSTRUCTIVE (COPD)
}

\author{
Daifiria $^{1}$, Muhammad Barkah Akbar ${ }^{2}$ \\ Fakultas Teknik \& Ilmu Komputer \\ Jurusan Teknik Informatika Universitas Potensi Utama \\ Jl. K.L.Yos Sudarso Km 6,5 No. 3A Tanjung Mulia Medan Sumatera Utara 20241 Indonesia \\ daifiria@potensi-utama.ac.id
}

\begin{abstract}
Abstrak
Sistem yang akan dirancang diharapkan mampu berfikir seperti seorang pakar. Sistem ini akan menggunakan metode theorema bayes untuk menghitung tingkat kemungkinan dan dapat memberikan tingkat kepastian diagnosa. Objek yang diteliti adalah penyakit paru obstruktif kronik, dimana masih banyak masyarakat yang belum mengetahui mengenai penyakit ini. Sistem ini akan memberikan informasi yang tepat kepada masyarakat mengenai penyakit paru obstruktif kronik, dan juga dapat memberikan pelayanan diagnosa awal terhadap penyakit ini.Menurut Global Initiative for Chronic Obstructive Lung Disease (GOLD), PPOK adalah penyakit dengan karakteristik keterbatasan saluran napas yang tidak sepenuhnya reversible. Keter-batasan saluran napas tersebut biasanya progresif dan berhubungan dengan respons inflamasi di-karenakan bahan yang merugikan atau gas. Penyakit paru obstruktif kronik merupakan penyakit sistemik yang mempunyai hubungan antara keterlibatan metabolik, otot rangka dan molekuler genetik. Keterbatasan aktivitas merupa-kan keluhan utama penderita PPOK yang sangat mempengaruhi kualitas hidup. Disfungsi otot rangka merupakan hal utama yang berperan dalam keterbatasan aktivitas penderita PPOK. Inflamasi sistemik, penurunan berat badan, peningkatan risiko penyakit kardiovaskuler, osteoporosis, dan depresi merupakan manifestasi sistemik PPOK.Adapun tujuan penelitian ini adalah untuk menganalisa dan merancang suatu sistem yang dapat mengidentifikasi dan memastikan penyakit paru obstruktif kronik berdasarkan gejala yang tampak dan untuk membantu masyarakatuntuk dapat mengetahui lebih dini mengenai penyakit ini.
\end{abstract}

Kata Kunci :Sistem Pakar, PPOK, Theorema Bayes.

\begin{abstract}
The system to be designed is expected to be able to think like an expert. The system will use the bayes theorem method to calculate probability levels and can provide a degree of diagnostic certainty. Objects studied are chronic obstructive pulmonary disease, where there are still many people who do not know about this disease. This system will provide people with appropriate information about chronic obstructive pulmonary disease, and can also provide early diagnostic services for the disease. According to the Global Initiative for Chronic Obstructive Lung Disease (GOLD), COPD is a disease with airway limitation characteristics that are not completely reversible. The airway constraints are usually progressive and are associated with an inflammatory response in due to harmful materials or gases. Chronic obstructive pulmonary disease is a systemic disease that has a relationship between metabolic involvement, skeletal muscle and molecular genetic. Activity limitations are the main complaints of people with COPD that greatly affect the quality of life. Skeletal muscle dysfunction is the main thing that plays a role in the limited activity of people with COPD. Systemic inflammation, weight loss, increased risk of cardiovascular disease, osteoporosis, and depression are systemic manifestations of COPD. The purpose of this study is to analyze and design a system that can identify and confirm chronic
\end{abstract}


obstructive pulmonary disease based on apparent symptoms and to help people to find out earlier about the disease.

\section{Keywords :Expert System, COPD, Bayes Theorem.}

\section{PENDAHULUAN}

Dalam bidang kedokteran teorema Bayes dikenal lebih banyak diterapkan dalam logika kedokteran modern. Teorema ini lebih banyak diterapkan pada hal-hal yang berkenaan dengan diagnose secara statistik yang berhubungan dengan probabilitas serta kemungkinan dari penyakit dan gejala-gejala yang berkaitan. Sebelum mendeskripsikan bagaimana teorema Bayes digunakan untuk klasifikasi, disusun masalah klasifikasi dari sudut pandang statistik. Jika $X$ melambangkan set atribut data dan $Y$ melambangkan kelas variabel. Jika variabel kelas memiliki hubungan non deterministicdengan atribut, maka dapat diperlakukan $X$ dan $Y$ sebagai variabel acak dan menangkap hubungan peluang menggunakan $P(Y \mid X)$. Peluang bersyarat ini juga dikenal dengan posterior peluang untuk $Y$, dan sebaliknya peluang prior $P(Y)[1]$.

Penyakit paru obstruktif kronik merupakan penyakit sistemik yang mempunyai hubungan antara keterlibatan metabolik, otot rangka dan molekuler genetik. Keterbatasan aktivitas merupakan keluhan utama penderita PPOK yang sangat mempengaruhi kualitas hidup. Disfungsi otot rangka merupakan hal utama yang berperan dalam keterbatasan aktivitas penderita PPOK. Inflamasi sistemik, penurunan berat badan, peningkatan risiko penyakit kardiovaskuler, osteoporosis, dan depresi merupakan manifestasi sistemik PPOK [2].

Pada penelitian ini penulis menerapkan metode Teorema bayes untuk mengidentifikasi penyakit PPOK. Sehingga dapat membantu dalam memberikan nilai kepastian terhadap penyakit yang diakibatkan bakteri tersebut.

\section{METODE PENELITIAN}

Metodologi penelitian akan sangat membantu penulis dalam proses penyelesaian masalah. penelitian ini memiliki beberapa tahapan dalam pelaksanaan kegiatan yang tertuang pada kerangka kerja penelitian.

1. Tempat dan Waktu Penelitian

Penelitian dilakukan di Klinik Paru Soeroso, Jl. Gagak Hitam (Ringroad Medan), Kota Medan..

2. Data

Penyusunan penelitian ini menggunakan data-data yang mendukung pelaksanaan dari proses penelitian yang dilakukan. Adapun hal-hal yang menyangkut data-data tersebut adalah sebagai berikut:

a. Sumber data

Data yang digunakan dalam penelitian ini diperoleh dari hasil diagnosis dan laboratorium.

b. Jenis data

Pada penelitian ini digunakan jenis data primer yaitu data diperoleh melalui observasi secara langsung, dan data sekunder yaitu data yang didapatkan dari studi kepustakaan.

c. Metode Pengumpulan Data

Metode yang digunakan dalam rangka pengumpulan data-data yang diperlukan dalam penelitian ini adalah sebagai berikut:

1. Studi literatur dari sumber-sumber kepustakaan sebagai landasan dalam menganalisis permasalahan yang disusun dalam penelitian ini. 
2. Pengumpulan data yang diperoleh dari hasil riset di Klinik Paru Soeroso, Jl. Gagak Hitam (Ringroad Medan), Kota Medan..

3. Analisis Data

Berdasarkan data yang telah diperoleh, maka pembahasan penelitian ini dilakukan dengan langkah-langkah sebagai berikut:

1. Mengumpulkan Data

2. Studi Literatur

3. Pembuatan Rule Based

4. Penerapan Metode Teorema bayes

5. Kesimpulam

4. Theorema Bayes

a. Pengertian

Dalam buku Wibisono (2009) dituliskan bahwa teori Bayes atau yang lebih dikenal dengan kaidah Bayes memainkan peranan yang sangat penting dalam penerapan probabilitas bersyarat.

Teori Bayes dikemukakan oleh seorang pendeta Inggris pada tahun 1763 yang bernama Thomas Bayes. Teori Bayes ini kemudian disempurnakan oleh Laplace. Teori Bayes digunakan untuk menghitung probabilitas terjadinya suatu peristiwa berdasarkan pengaruh yang didapat dari hasil observasi. Teori Bayes merupakan kaidah yang memperbaiki atau merevisi suatu probabilitas dengan cara memanfaatkan informasi tambahan. Maksudnya, dari probabilitas awal (prior probability) yang belum diperbaiki yang dirumuskan berdasarkan informasi yang tersedia saat ini, kemudian dibentuklah probabilitas berikutnya (posterior probability).

b. Rumus

1. Probabilitas dan Teorema Bayes

Probabilitas Bayes merupakan salah satu cara yang baik untuk mengatasi ketidakpastian data dengan menggunakan formula bayes yang dinyatakan dengan rumus [4]:

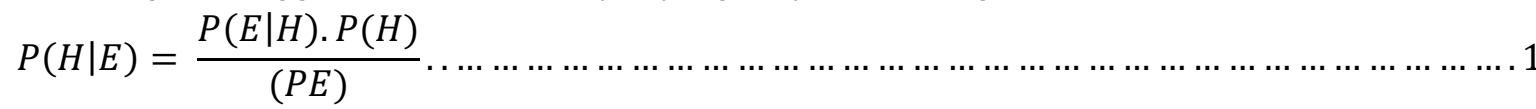

Keterangan :

$\mathrm{P}(\mathrm{H} \mid \mathrm{E})$ : probabilitas hipotesis $\mathrm{H}$ jika diberikan evidence $\mathrm{E}$.

$\mathrm{P}(\mathrm{E} \mid \mathrm{H})$ : probabilitas munculnya evidence apapun.

$\mathrm{P}(\mathrm{E})$ : probabilitas evidence $\mathrm{E}$

Dalam bidang kedokteran teorema Bayes sudah dikenal tapi teorema ini lebih banyak diterapkan dalam logika kedokteran modern (Cutler: 1991).Teorema ini lebih banyak diterapkan pada hal-hal yang berkenaan dengan probabilitas serta kemungkinan dari penyakit dan gejalagejala yang berkaitan.

2. Perhitungan Dengan Teorema Bayes

Secara umum teorema Bayes dengan E kejadiandan Hipotesis H dapat dituliskan dalam bentuk :

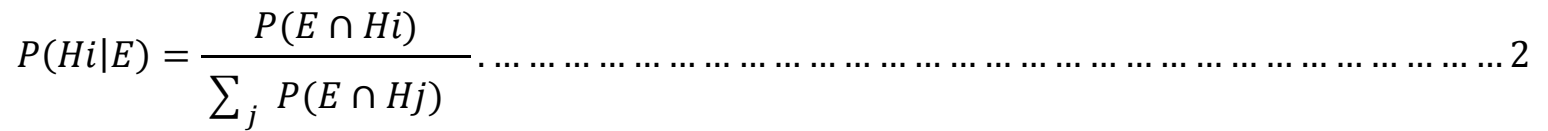

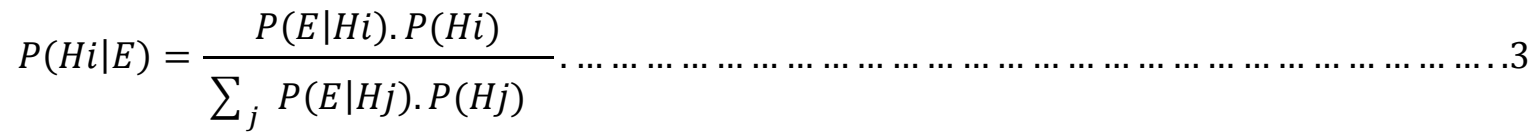

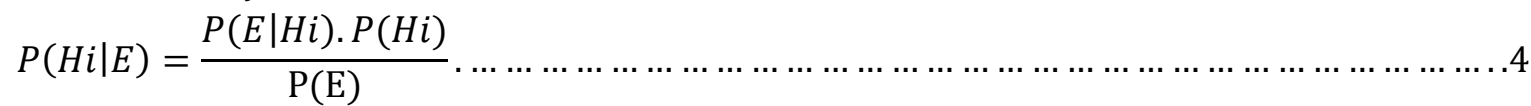


Teorema Bayes dapat dikembangkan jika setelah dilakukan pengujian terhadap hipotesis kemudian muncul lebih daris satu evidence. Dalam hal ini maka persamaan nya akan menjadi:

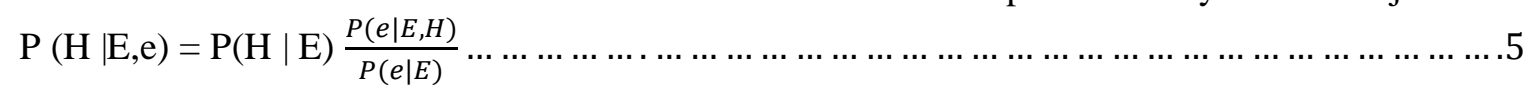

Keterangan :

$\mathrm{E} \quad$ : evidence baru

$\mathrm{P}(\mathrm{H} \mid \mathrm{E}, \mathrm{e}) \quad$ : probabilitas hipotesis $\mathrm{H}$ benar jika muncul evidence baru $\mathrm{E}$ dari evidence baru $\mathrm{E}$ dari evidence lama e.

$\mathrm{P}(\mathrm{H} \mid \mathrm{E}) \quad$ : probabilitas hipotesis $\mathrm{H}$ benar jika diberikan evidence $\mathrm{E}$.

$\mathrm{P}(\mathrm{e} \mid \mathrm{E}, \mathrm{H}) \quad$ : kaitan antar e dan $\mathrm{E}$ jika hipotesis $\mathrm{H}$ benar.

$\mathrm{P}(\mathrm{e} \mid \mathrm{E}) \quad$ : kaitan antara e dan $\mathrm{E}$ tanpa memandang hipotesis apapun.

\section{HASIL DAN PEMBAHASAN}

\subsection{Pembahasan}

\section{a. Data Gejala PPOK}

Sebelum menentukan hasil diagnosa, terlebih dahulu kita harus menyediakan data-data yang dibutuhkan. Proses diagnosa penyakit sistem pakar ini adalah berdasarkan gejala yang tampak pada pasien. Berikut merupakan data-data gejala yang diakibatkan jika seseorang terkena PPOK berdasarkan penelitian yang dilakukan seperti pada table 1 [3].

Tabel 1. Data Gejala PPOK

\begin{tabular}{|l|l|l|l|}
\hline No & Gejala & Bakteri & Pengobatan \\
\hline 1 & $\begin{array}{l}\text { Batuk Berdahak yang Tidak Kunjung } \\
\text { Sembuh }\end{array}$ & & $\begin{array}{l}\text { Gunakan inhaler (obat hirup) } \\
\text { jenis pereda gejala atau } \\
\text { inflamasi saluran pernapasan, } \\
\text { tablet teofilin yang akan } \\
\text { melebarkan saluran } \\
\text { pernapasan, tablet mukolitik } \\
\text { (pengencer dahak dan ingus), } \\
\text { tablet antibiotik, serta tablet } \\
\text { steroid. }\end{array}$ \\
\hline 3 & Makin sering tersengal-sengal \\
\hline 4 & Mengi atau napas sesak dan berbunyi & PPOK & \\
\hline 5 & Sering mengalami infeksi paru & & \\
\hline 6 & Penurunan berat badan & & \\
\hline
\end{tabular}

b. Perhitungan Teorema Bayes

Sebelum melakukan perhitungan dengan teorema bayes, terlebih dahulu harus menentukan nilai bobot dari setiap gejala terhadap PPOK. Nilai bobot dari masing-masing gejala ditunjukkan pada tabel 2 sebagai berikut :

Tabel 2. Nilai Bobot Gejala

\begin{tabular}{|c|c|c|}
\hline Kode Gejala & Gejala & Nilai Densitas \\
\hline G01 & Batuk berdahak yang tidak kunjung sembuh & 0.8 \\
\hline G02 & Makin sering tersengal-sengal & 0.8 \\
\hline G03 & Mengi atau napas sesak dan berbunyi & 0.7 \\
\hline G04 & Lemas & 0.5 \\
\hline
\end{tabular}




\begin{tabular}{|c|c|c|}
\hline G05 & Sering mengalami infeksi paru & 0.9 \\
\hline G06 & Penurunan berat badan & 0.7 \\
\hline
\end{tabular}

Perhitungan teorema bayes dilakukan untuk contoh kasus PPOK. Pasien atau pengguna sistem akan diberikan pertanyaan-pertanyaan yang harus dijawab. Setelah dilakukan penelusuran, pengguna menjawab pertanyaan sebagai berikut :

$$
\begin{array}{ll}
\mathrm{G} 01= & 0.8=\mathrm{P}(\mathrm{E} \mid \mathrm{H} 1) \\
\mathrm{G} 02= & 0.8=\mathrm{P}(\mathrm{E} \mid \mathrm{H} 2) \\
\mathrm{G} 05= & 0.9=\mathrm{P}(\mathrm{E} \mid \mathrm{H} 5)
\end{array}
$$

Kemudian mencari nilai semesta dengan menjumlahkan dari hipotesa di atas :

$$
\sum_{k=1}^{6}=\mathrm{G} 01+\mathrm{G} 02+\mathrm{G} 05
$$$$
=0.8+0.8+0.9
$$$$
=2.5
$$

Setelah hasil penjumlahan di atas diketahui, maka didapatlah rumus untuk menghitung nilai semesta adalah sabagai berikut :

$$
\begin{aligned}
& P(H 1)=\frac{H 1}{\sum_{k=1}^{6}}=\frac{0.8}{2.5}=0.32 \\
& P(H 2)=\frac{H 2}{\sum_{k=1}^{6}}=\frac{0.8}{2.5}=0.32 \\
& P(H 5)=\frac{H 5}{\sum_{k=1}^{6}}=\frac{0.9}{2.5}=0.36
\end{aligned}
$$

Setelah nilai $\mathrm{P}(\mathrm{Hi})$ diketahui, probabilitas hipotesis $\mathrm{H}$ tanpa memandang evidence apapun, maka langkah selanjutnya adalah :

$$
\begin{aligned}
\sum_{k=1}^{7} & =\mathrm{P}(\mathrm{Hi}) * \mathrm{P}(\mathrm{E} \mid \mathrm{Hi}-\mathrm{n}) \\
& =(P(H 1) * P(E \mid H 1))+(P(H 2) * P(E \mid H 2))+(P(H 5) * P(E \mid H 5)) \\
& =(0.32 * 0.8)+(0.32 * 0.8)+(0.36 * 0.9) \\
& =(0.256)+(0.256)+(0.324) \\
& =0.836
\end{aligned}
$$

Langkah selanjutnya ialah mencari nilai $\mathrm{P}(\mathrm{Hi} \mid \mathrm{E})$ atau probabilitas hipotesis $\mathrm{Hi}$ benar jika diberikan evidence $\mathrm{E}$.

$$
\begin{aligned}
& \mathrm{P}(\mathrm{H} 1 \mid E)=\frac{0.8 * 0.32}{0.836}=0.3062 \\
& \mathrm{P}(\mathrm{H} 2 \mid E)=\frac{0.8 * 0.32}{0.836}=0.3062 \\
& \mathrm{P}(\mathrm{H} 5 \mid E)=\frac{0.9 * 0.36}{0.836}=0.3876
\end{aligned}
$$

Setelah seluruh nilai $\mathrm{P}(\mathrm{Hi} \mid \mathrm{E})$ diketahui, maka jumlahkan seluruh nilai bayesnya dengan rumus sebagai berikut :

$$
\begin{aligned}
& \sum_{k=1}^{6} \text { Bayes }=\text { Bayes } 1+\text { Bayes } 2+\text { Bayes } 3 \\
& =(0.8 * 0.3062)+(0.8 * 0.3062)+(0.9 * 0.3876) \\
& =0.83876 * 100 \%=83.876 \%
\end{aligned}
$$


Dari hasil perhitungan gejala dengan teorema bayes diketahui pasien atau pengguna sistem terindikasi terkena penyakit paru obstruktif kronis dengan tingkat probabilitas sebesar $83.876 \%$.

\section{c. Desain Sistem}

Desain sistem dengan menggunakan Activity diagram. Activity diagram menggambarkan berbagai alur aktivitas secara umum dalam sistem yang sedang dirancang, bagaimana masingmasing alur berawal, proses yang dilakukan dan bagaimana proses berakhir. Berikut merupakan desain aktifitas diagran seperti pada gambar 1 .

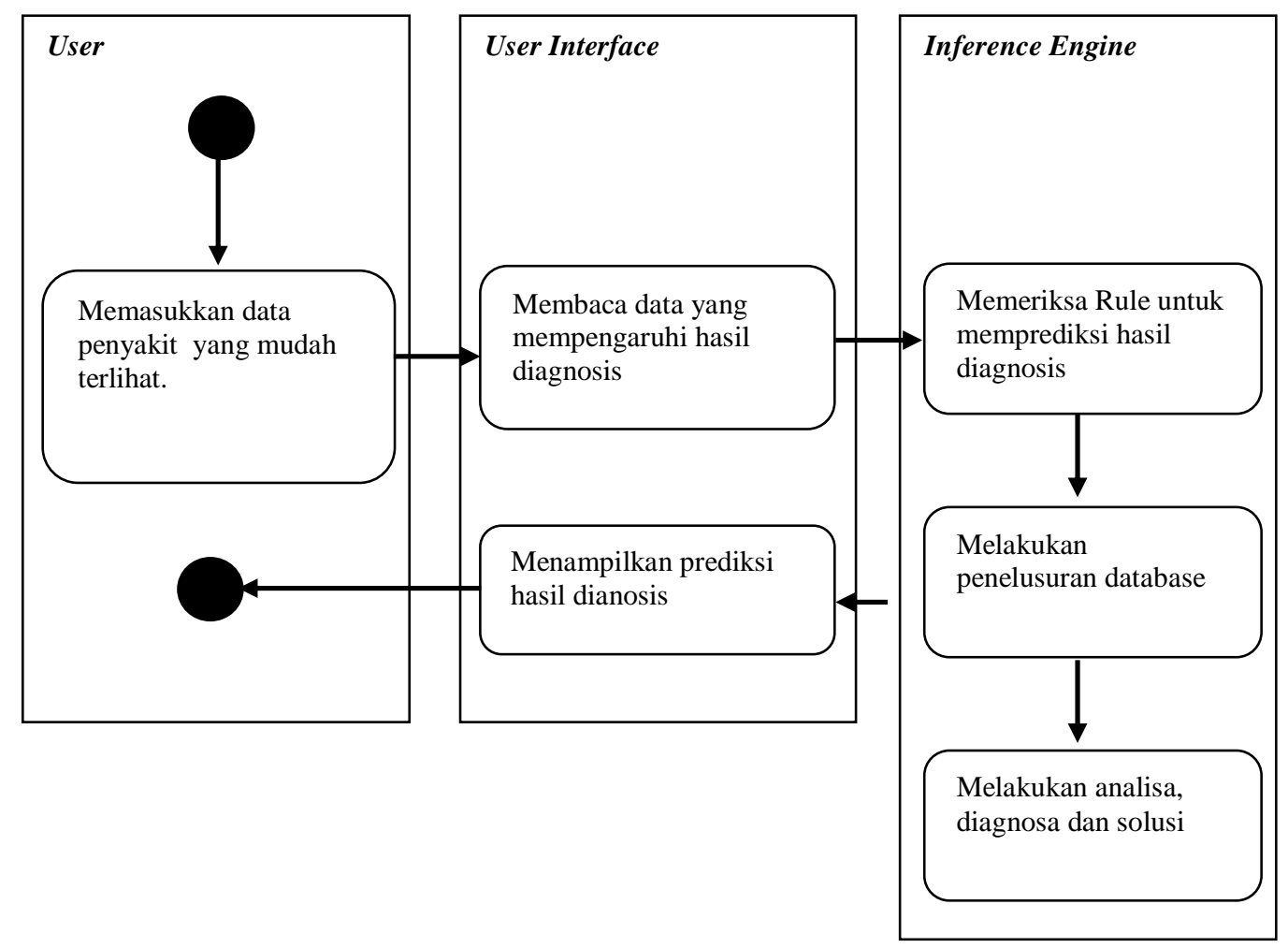

Gambar 1. Desain Aktivitas Sistem Pakar

\subsection{Hasil}

Hasil yang diperoleh dari penelitian ini yaitu suatu aplikasi sistem pakar yang dapat digunakan untuk mendiagnosa penyakit paru obstruktif kronik. Adapun rincian dari aplikasi yang dirancang adalah sebagai berikut :

\section{FormLogin}

Form Login dirancang untuk muncul pertama sekali pada saat aplikasi sistem pakar dijalankan. Form ini berguna untuk masuk ke dalam sistem. Jika pengguna adalah seorang pakar, maka pakar harus memasukkan username dan password yang sudah tersimpan di database. Namun jika user adalah pemakai yang ingin berkonsultasi, maka ia dapat langsung masuk ke dalam sistem. Form login ini dibuat supaya orang yang tidak berkepentingan tidak dapat sembarangan masuk ke dalam sistem, dan tidak dapat merusak basis pengetahuan yang sudah ada. Adapun desain form login dalam sistem pakar ini adalah seperti gambar 2 . 


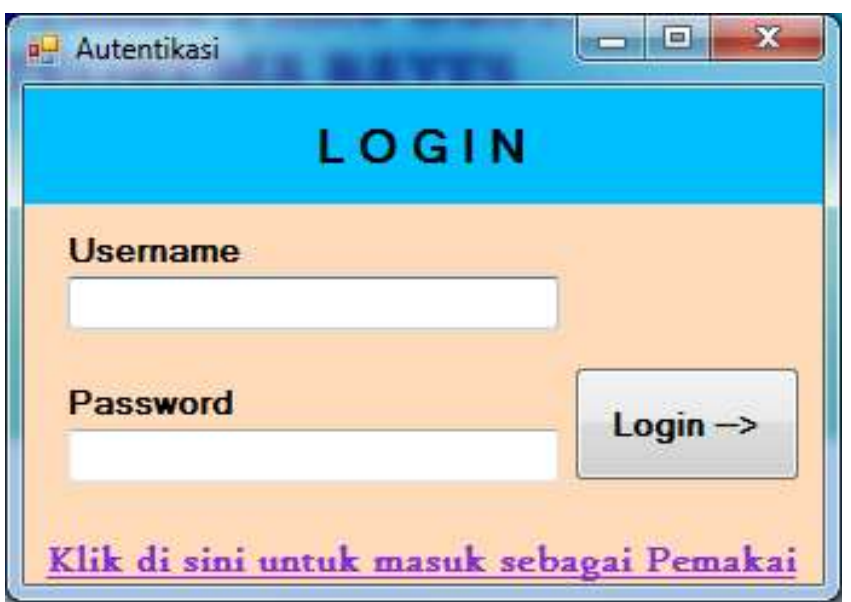

Gambar 2. Form Login

2. Form Beranda Pakar

Form beranda pakar dirancang untuk pakar, di mana form ini akan muncul setelah pakar sukses login pada saat aplikasi sistem pakar ini dijalankan. Form beranda berfungsi untuk menampilkan menu utama yang ingin dituju. Berikut merupakan tampilan form beranda seperti terlihat pada gambar 3 .

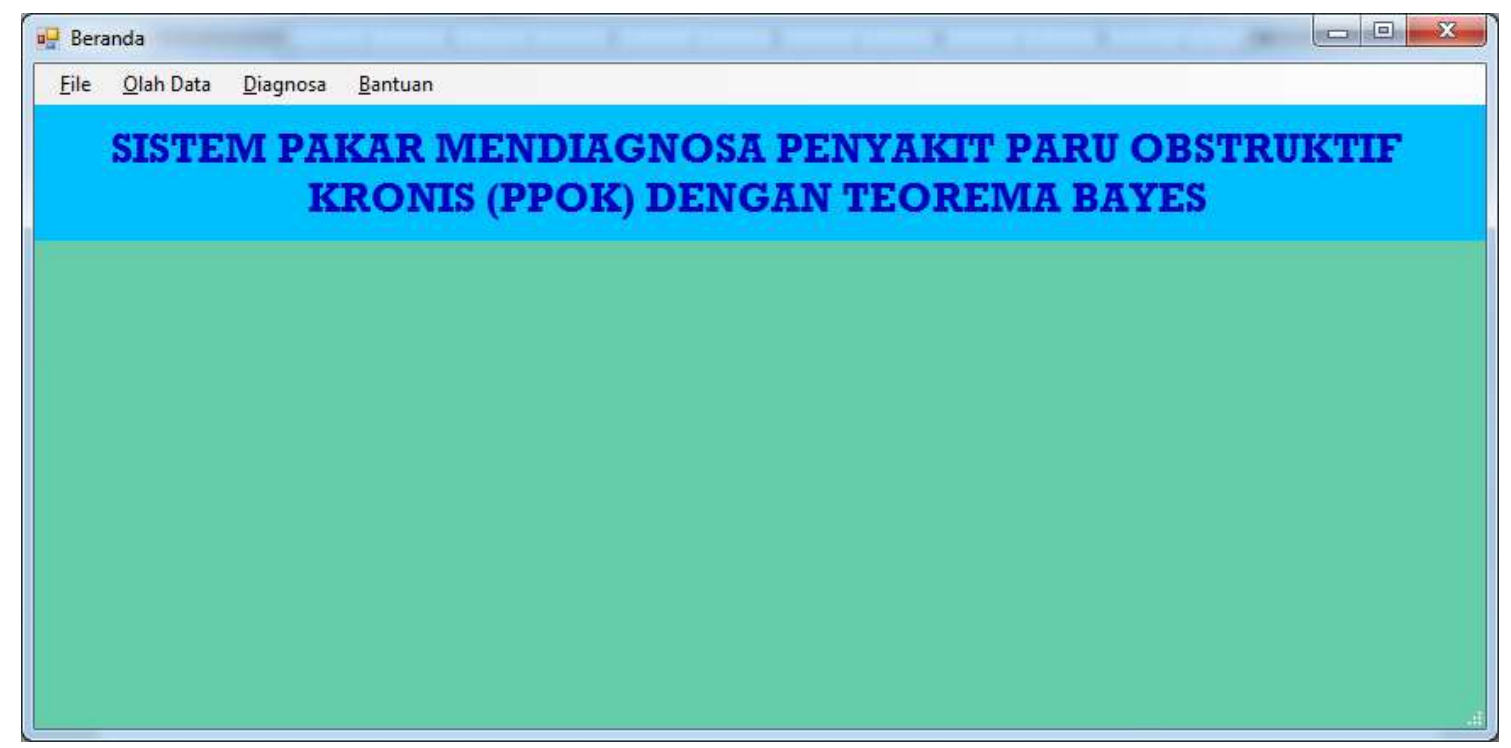

Gambar 3. Form Beranda

\section{Form Beranda Pemakai}

Form beranda pemakai dirancang untuk pemakai secara umum. Form beranda berfungsi untuk menampilkan menu utama yang ingin dituju oleh pemakai. Berikut merupakan tampilan form beranda seperti terlihat pada gambar 4 . 


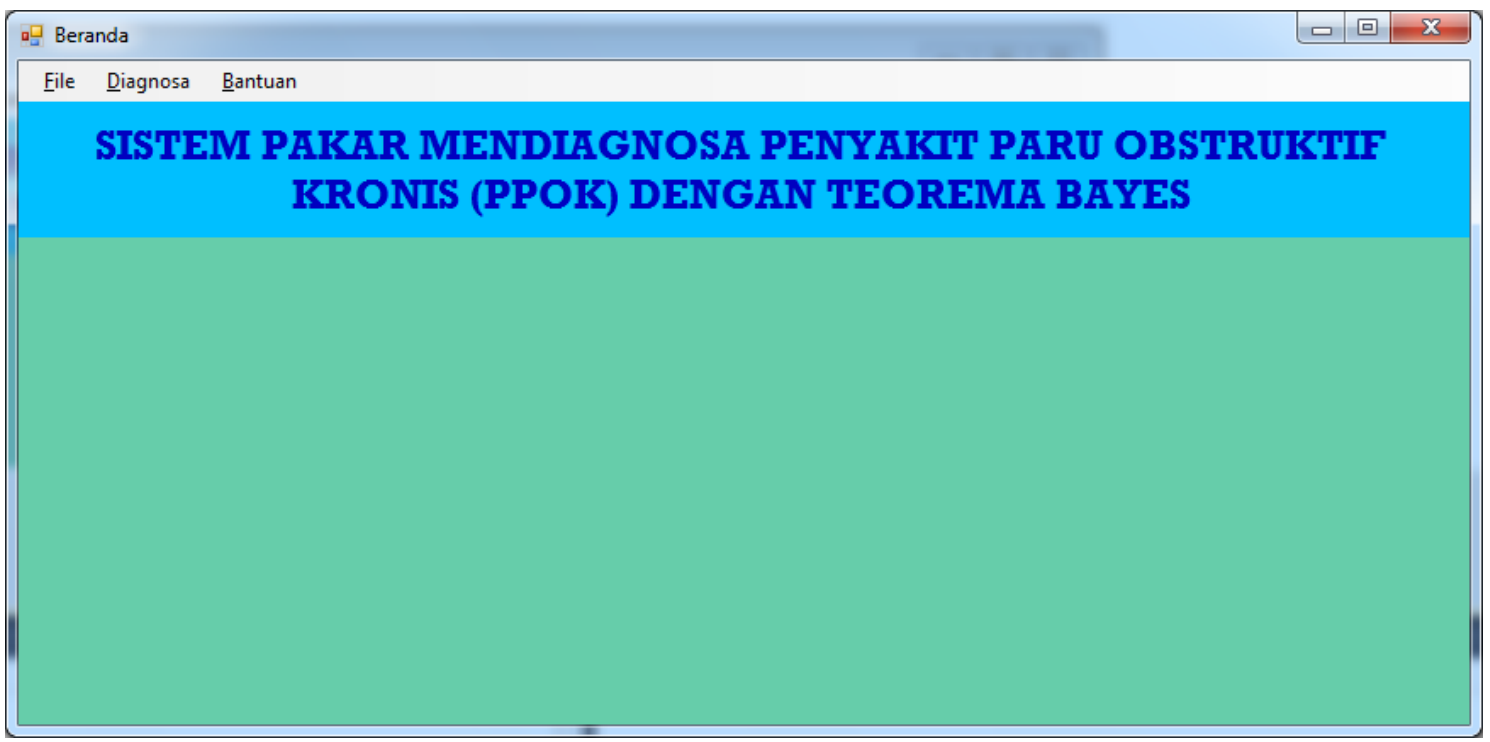

Gambar 4. Form Beranda Pemakai

\section{Form Diagnosa}

Pada form diagnosa ini pemakai akan diwajibkan memilih jawaban ya atau tidak sesuai dengan gejala-gejala yang mereka alami. Dalam form ini. Form tersebut terdiri dari 2 buah tombol sebagai pilihan jawaban pemakai. Jika semua pertanyaan sudah habis dijawab maka mesin inferensi akan menelusuri penyakit yang ditimbulkan berdasarkan ciri gejala tersebut dan akan tampil juga solusi untuk penanganannya. Tampilan form penelusuran dapat dilihat pada gambar 5 .

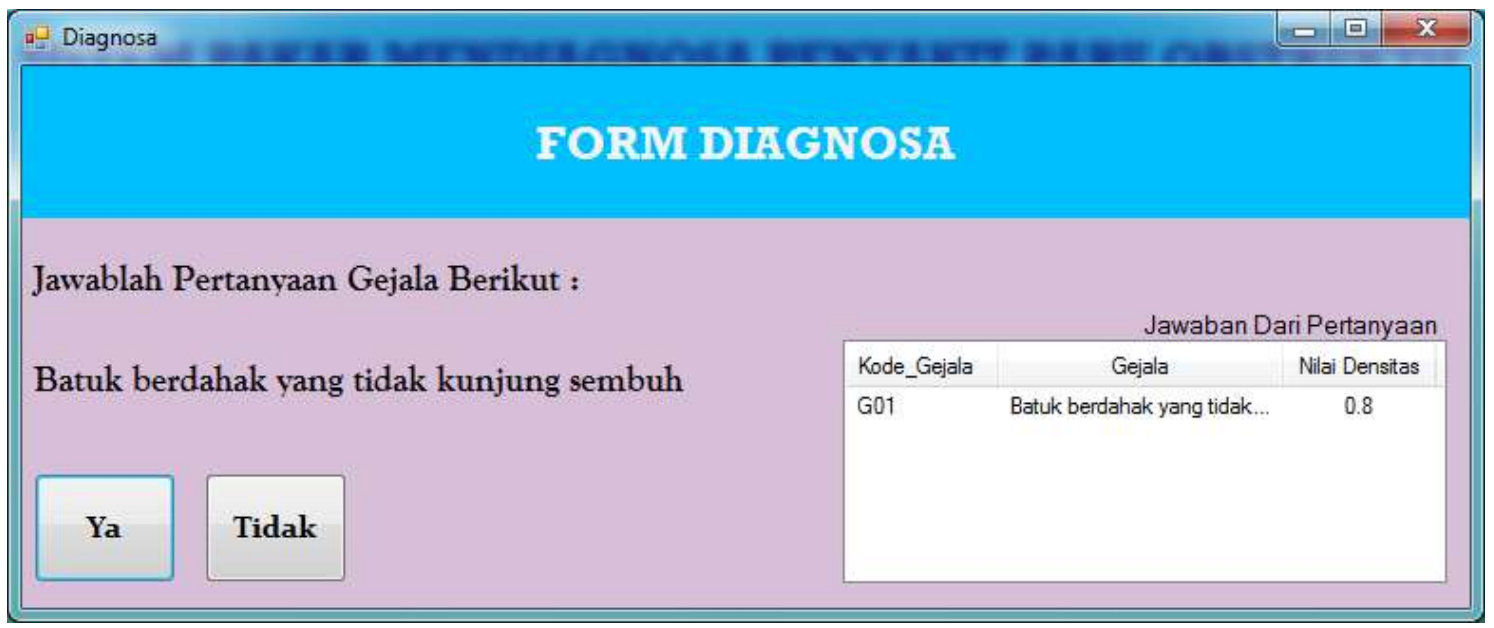

Gambar 5. Form Diagnosa

\section{Form Data Pengetahuan}

Di dalam form ini pakar akan memasukkan pertanyaan-pertanyaan dengan fakta-fakta ya dan dengan fakta tidak. Dalam form ini terdapat 4 buah tombol yaitu tombol save, tombol edit, tombol delete, dan tombol keluar. Berikut merupakan tampilan dari form basis aturan (rule base) seperti terlihat pada gambar 6 berikut. 


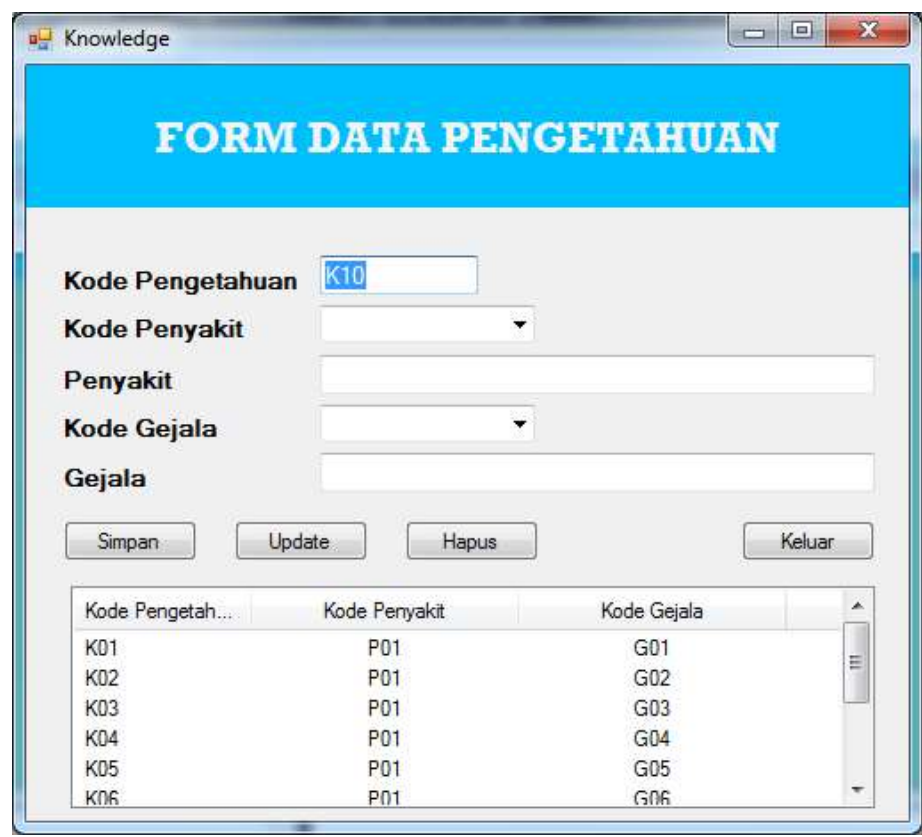

Gambar 6. Form Data Pengetahuan

\section{Form DataPenyakit}

Untuk dapat melihat penyakit yang diderita serta solusinya maka dibuat sebuah form penyakit. Terdapat 4 buah tombol dalam form tersebut yaitu tombol save, tombol delete, tombol edit, dan tombol keluar. Tampilan form penyakit tersebut dapat dilihat pada gambar 7 .

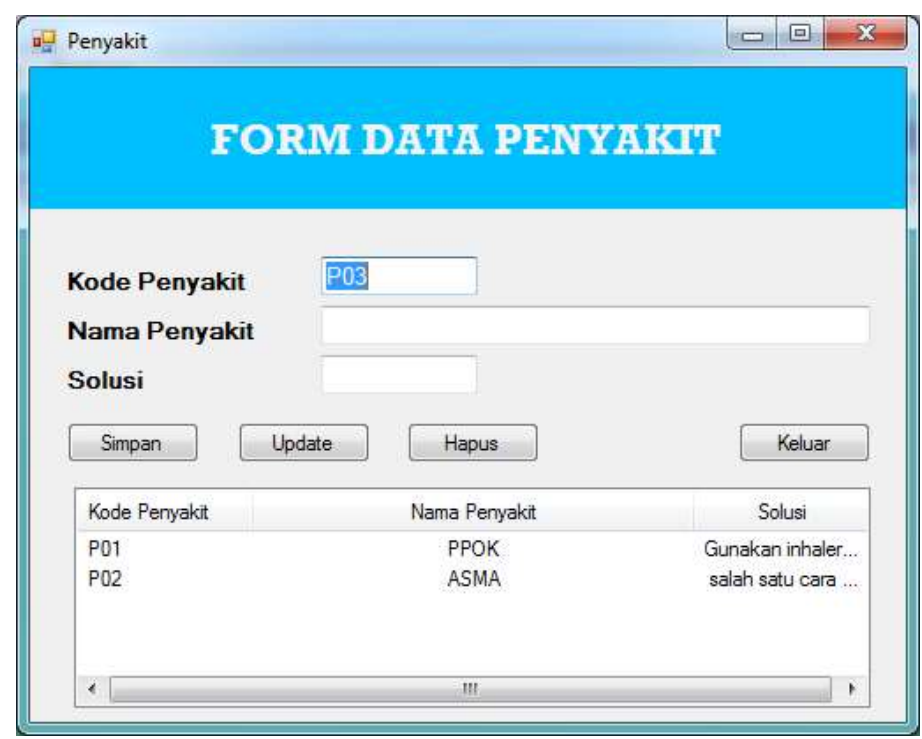

Gambar 7. Form Data Penyakit

\section{Form Gejala}

Untuk dapat melihat gejala yang terdapat pada PPOK maka dibuat sebuah form gejala. Terdapat 4 buah tombol dalam form tersebut yaitu tombol simpan, tombol delete, tombol update, dan tombol keluar. Tampilan form gejala tersebut dapat dilihat pada gambar 8 . 


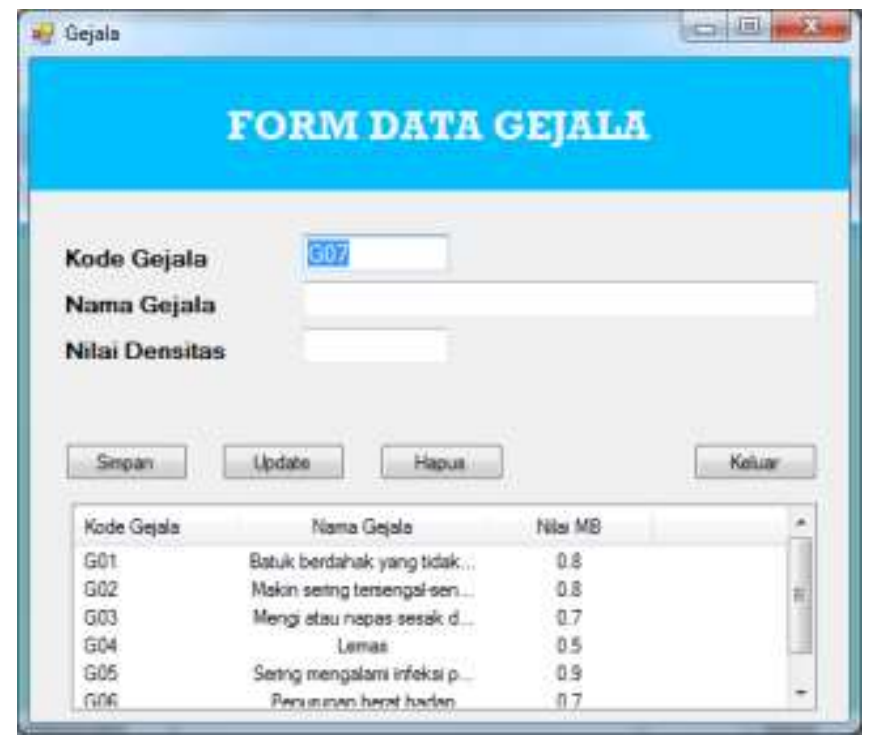

Gambar 8. Form Data Gejala

\section{KESIMPULAN}

Berdasarkan penelitian dan pembahasan yang dilakukan, maka dapat disimpulkan bahwa sistem pakar yang dirancang dapat mendiagnosa penyakit paru obstruktif kronis. Kecepatan dalam mendiagnosa penyakit akan membantu praktisi kesehatan di bawah Dokter untuk mendiagnosa penyakit melalui bantuan rule-rule yang disediakan, semakin banyak rule-rule yang dimasukkan maka tingkat keakurasian dan ketepatan hasil diagnosa semakin tepat. Teorema bayes bisa digunakan untuk melakukan perhitungan kemungkinan untuk mendapatkan hasil diagnosa penyakit berdasarkan gejala-gejala yang ada.

\section{SARAN}

Sebagai akhir dari penelitian ini, kami ingin menyampaikan saran-saran yang mungkin bermanfaat bagi siapa saja yang berminat untuk menggunakan sistem ini yaitu dengan pengembangan sistem pakar ini, jumlah rule-rule yang dignakan agar lebih banyak lagi sehingga untuk hasil diagnosa bisa mendapatkan hasil yang lebih baik lagi.

\section{UCAPAN TERIMA KASIH}

Penulis mengucapkan terima kasih kepada DRPM Ditjen Penguatan Risbang yang telah mendanai penelitian ini dan juga kepada Universitas Potensi Utama Karena telah memberikan dukungan dan perhatian terhadap penelitian ini.

\section{DAFTAR PUSTAKA}

[1] Hartatik, I Ketut Putra Yasa. 2015. "Sistem Pakar Untuk Mendeteksi Hama Tanaman Jahe Menggunakan Teorema Bayes". Jurnal Ilmiah DASI Vol. 16 No. 02.

[2] Ratih Oemiati. 2013. "Kajian Epidemiologis Penyakit Paru Obstruktif Kronik (PPOK)". Media Litbangkes Vol 23 No 2. Pusat Teknologi Intervensi Kesehatan Masyarakat Badan Penelitian dan Pengembangan Kesehatan, Kementerian Kesehatan RI. Jakarta.

[3] Heidy Agustin dan Faisal Yunus. 2008. "Proses Metabolisme pada PPOK”. J Respir Indo vol 28 
no 3 Juli, 2008.

[4] Fithri, Laily Diana. 2013. "Sistem Pendeteksian Penyimpangan Tingkah Laku Anak Usia 0 Sampai 3 Tahun Dengan Metode Bayesian”. Jurnal SIMETRIS, Vol 4 No 1. 